\title{
健康茶を添加したクッキーの抗酸化能
}

\author{
杉山 薰*·冨岡和子** \\ (*奈良教育大学, **元 奈良教育大学)
}

\section{The antioxidant ability of various health teas in cookies}

\author{
Kaoru Sugiyama*, Kazuko Tomioka** \\ *Nara University of Education, Takabatake-cho, Nara-shi, Nara, 630-8528, Japan \\ *テ630-8528 奈良県奈良市高畑町
}

\begin{abstract}
The antioxidant abilities of various health teas (i.e., lotus leaf, striped bamboo, persimmon leaf, mugwort, perilla, cedar leaf or dokudami) both singly and in cookies containing these individual teas were examined using a powder model system in the water activity (Aw) range of $0.2-1.0$ at $50{ }^{\circ} \mathrm{C}$.

Potato starch (control) had no antioxidant ability over the entire investigated Aw range. The peaks of the peroxide value (PV) appeared for the lotus leaf and striped bamboo in the Aw range of 0.2-0.8 and for the persimmon leaf at Aw0.2-0.4. Those $\mathrm{PV}$ peaks did not appear for the mugwort, perilla, cedar leaf and dokudami in the entire Aw range.

Cookies were prepared by baking the dough at $160{ }^{\circ} \mathrm{C}$ for 20 minutes, which consisted of ingredients supporting oil (72\% soft flour, 3\% baking powder, $25 \%$ powdered health tea or potato starch), linoleic acid and water in the ratio 4:1:1.5 by weight. No antioxidant ability was obtained over the entire Aw range when potato starch (control) was added to the cookies. Although PV peaks for the cookies at a level similar to the control appeared with added persimmon leaf at lower than Aw0.4, no remarkable peaks were observed for the mugwort, perilla, cedar leaf and dokudami at higher than Aw0.6.
\end{abstract}

\section{1. 緒言}

これまでツバキ科の茶の抗酸化作用，抗菌作用，抗が 乙作用，血圧上昇抑制作用，血糖值上昇抑制作用などが 報告され成書にまとめられている1) 4)。この流れに沿い, 近年ツバキ科の茶以外の葉にも, ツバキ科の茶と同様に, その乾燥処理後の熱水抽出液に健康増進効果があること が認められ ${ }^{5)}$, 健康茶として広く飲用される傾向にある。 このうち油脂酸化防止能 (抗酸化能) に関するものは, 体内に入った後の作用や1,1-Diphenyl-2-picrylhydrazyl (DPPH) ラジカル捕捉活性に重点が置かれ6）～10)著者 らがこれまで着目してきた食品の一般的な形態である固 体状態での抗酸化能の評価は人見らによる鉄含有クッ キーに提るルイボスティーの効果について検討したも のがあるが11)，著者らが注目してきた水分活性（Aw）
との関連については言及していない。著者らは, 一連の 乾燥粉末系での食品抢よび食品成分の抗酸化能の検討で, タンパク質抢よび構成ペプチド, アミノ酸 ${ }^{12)}$, 糠や酒粕 などの食品製造副産物 ${ }^{13)}$, コーヒー, ココアなどの嗜好 品 ${ }^{14)}$, 葛葉抢よび葛粉製造の際に発生する葛根水抽出物 (葛水) 乾燥粉末 ${ }^{15)}$ が乾燥粉末系で有効であること, な らびに抗酸化能は保温中の Awに大きく左右され，一 般的には中間〜高 $\mathrm{Aw}$ 領域で良好であることが明らか になった。本研究では, 現在健康茶として飲用されてい る数種の茶葉 (健康茶葉) の乾燥粉末系に抢ける抗酸化 能について検討した。

\section{2. 方 法}

\section{(1) 試料の調製}

市販の健康茶葉のうち, 八ス葉, クマザサ, 柿葉, ヨ 
モギ，シソ，杉葉（いずれも前田製茶工場製，兵庫県水 上郡山南町草部176番地), ドクダミ（クラモト, 兵庫県 水上郡南町小野尻123番地）を乳鉢で粉砕し，35メッシ ュの節にかけたものを試料とした。

（2）保温および過酸化物価（PV）の測定

健康茶葉粉末試料またはジャガイモデンプン (対照) ${ }^{14)}$ とリノール酸を重量比 4 ：1 で混合したものを50mg ず つ試験管に分取した。これを $\mathrm{Aw}$ 調整のために所定濃 度の硫酸を入れた密閉容器 $(25 \mathrm{~cm} \times 18 \mathrm{~cm} \times 13 \mathrm{~cm})$ に入 れ ${ }^{16)}$ ，酸素を充填後 $50^{\circ} \mathrm{C}$ で保温した。所定期間後，試験
管を取り出し PVの測定に供した。PVはクロロホル ムーメタノール（2：1 v/v）混合液で脂質を抽出後口 ダン鉄法で測定した ${ }^{17)}$ 。求めた PVはリノール酸 $1 \mathrm{~kg}$ 当たりの活性酸素のミリ当量数 (meq $/ \mathrm{kg}$ of linoleate) で表示した。試薬はすべてナカライテスク製を用いた。 (3) クッキーの調製

薄力粉 $72 \%$, 健康茶葉粉末試料またはジャガイモデン プン (対照) $25 \%$, ベーキングパウダー $3 \%$ を混合して 油脂支持体とした。この油脂支持体とリノール酸，水を 重量比 $4 ： 1 ： 1.50$ 組成で混合して生地とした。この
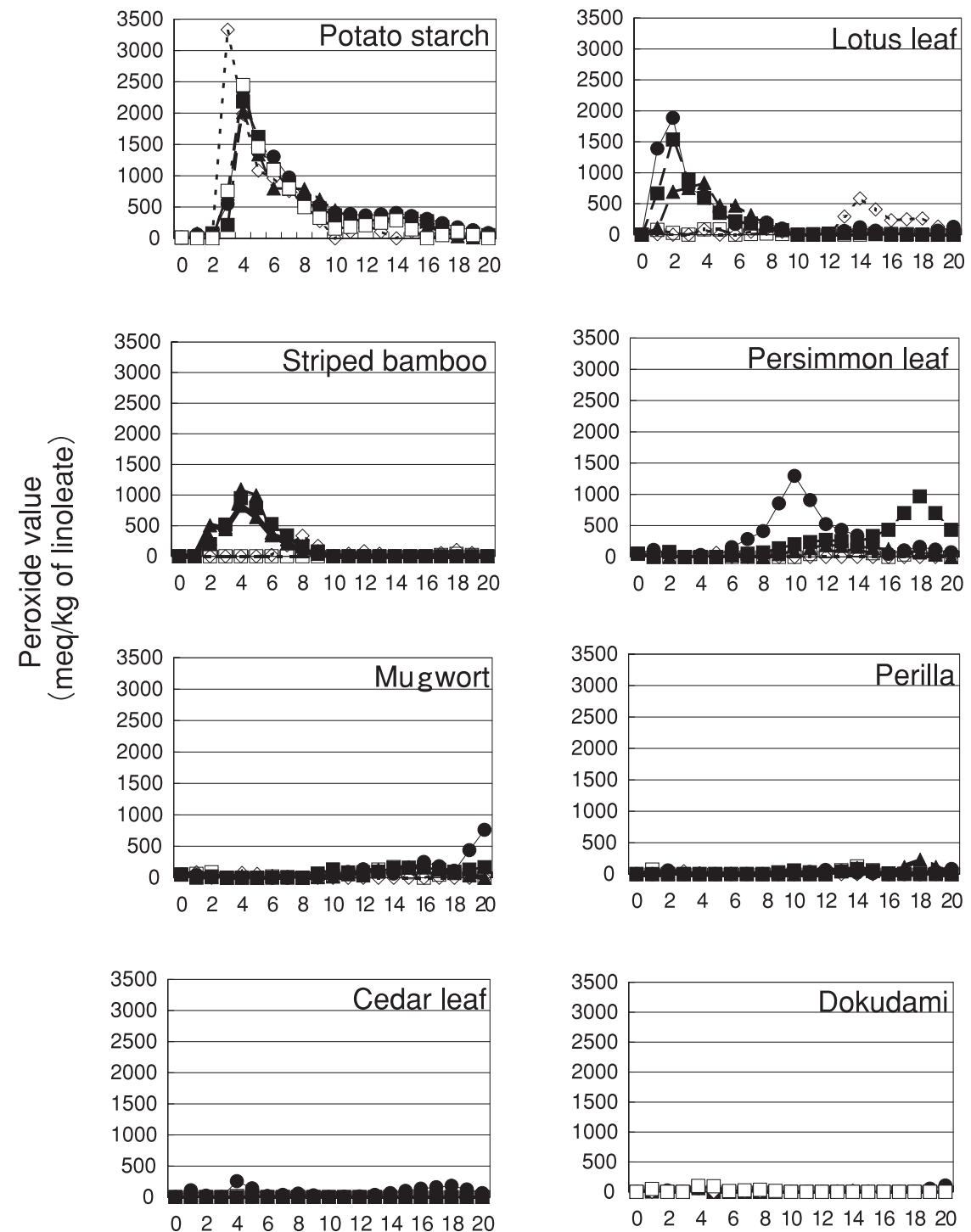

Storage period (day)

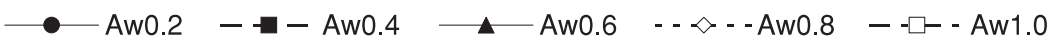

Fig. 1 Changes in peroxidation of linoleate with various health teas in a powder model system

Potato starch (control) or health teas individually and linoleic acid were mixed in the ratio $4: 1$ by weight in a mortar. The mixtures were divided into $50 \mathrm{mg}$ each, and stored in the sealed vessel with oxygen and controlled Aw by prescribed sulfuric acid at the range of Aw0.2-1.0, and at $50^{\circ} \mathrm{C}$. Peroxide values were estimated by the ferric thiocyanate method and described as milliequivalent of peroxide per kilogram of linoleate. 
生地を直径 $3 \mathrm{~cm}$, 厚さ $3 \mathrm{~mm}$ の円盤状にし, オーブン で $160{ }^{\circ} \mathrm{C} ， 20$ 分間焼成してクッキーを調製した。これを 室温で冷却後, 乳鉢で粉砕し粉末クッキー試料とした。 健康茶葉粉末試料と同様に保温し PVの変化を求めた。 薄力粉およびベーキングパウダーはいずれも日清製粉製 （前者商品名フラワー）を用いた。

\section{3. 結果および考察}

図 1 にジャガイモデンプン（対照）とハス葉，クマザ サ，柿葉，ヨモギ，シソ，杉葉，ドクダミの各健康茶葉 粉末試料における PV 変化を示した。対照では全 Aw 領 域で保温開始 4 日以内に1500を超す PV ピークが出現し た。ハス葉では, Aw1.0で保温期間を通じて PVの上昇 はみられなかったが，Aw0.8で14日目（PV585）, Aw 0.6 で4 日目 (PV873), Aw0.4で2 日目 (PV1536), Aw0.2で2 日目（PV1885）にピークが出現した。Aw が高領域から低領域に移るにしたがい保温期間中の PV ピークの出現が早まり, その值も高くなる傾向が認めら
れた。クマザサでもハス葉同様の傾向がみられた。すな わち，Aw1.0では PV上昇がみられなかったが， $\mathrm{Aw}$ 0.8では 8 日目 (PV335), Aw0.6では 4 日目 (PV1093), $\mathrm{Aw} 0.4$ では 4 日目 (PV948), Aw0.2では 4 日目（PV 825）にPVピークが出現した。一方, 柿葉では, Aw 0.4 以下の低 $\mathrm{Aw}$ 領域で1000前後の PV ピークが出現し たが，中間〜低 $\mathrm{Aw}$ 領域では $\mathrm{PV}$ 上昇は殆どみられなか った。これに対し，ヨモギ，シソ，杉葉，ドクダミには， 全保温期間を通して殆ど PVの上昇は認められなかった。 これらの結果を踏まえて, さらにジャガイモデンプン (対照), 柿葉, ヨモギ, シソ, 杉葉, ドクダミについて 各健康茶葉粉末試料を添加したクッキーを調製し, 保温 期間中の PV 変化を調べた。

図 2 にジャガイモデンプン（対照）および各健康茶葉 添加クッキーの保温期間中の PV 変化を示した。対照は, 全 Aw 領域で 6 日目までに1200を超える PVピークが出 現した。健康茶葉粉末試料に㧍いて Aw0.6以上の中間 〜高 Aw 領域で PVの上昇が抑えられた柿葉を添加した

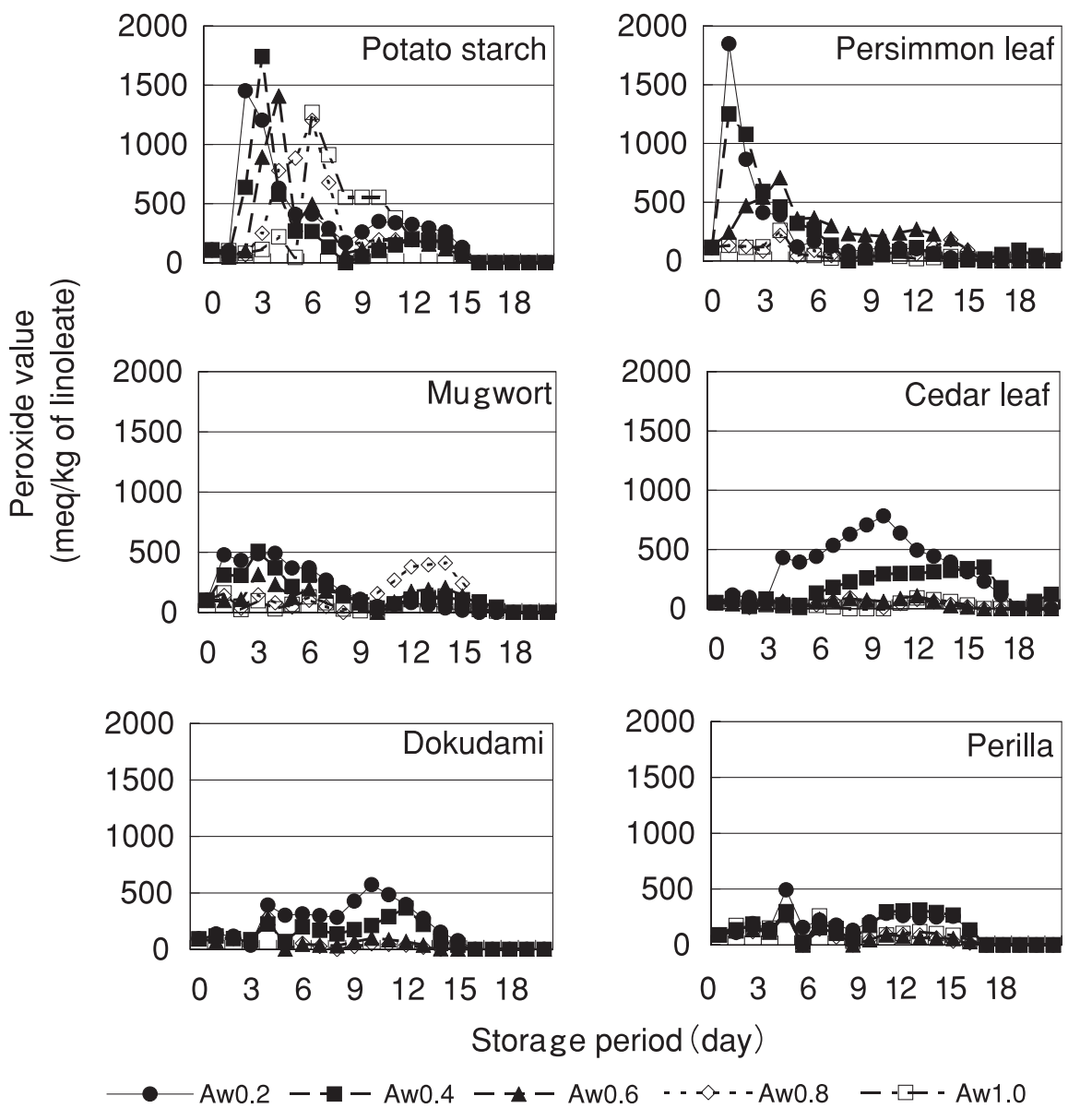

Fig.2 Changes in peroxidation of linoleate with cookies added various health teas in a powder model system

Cookies were prepared by baking of the dough at $160^{\circ} \mathrm{C}$ for 20 minutes, which consisted of stuffs supporting oil $(72 \%$ soft flour, $3 \%$ baking powder, $25 \%$ powdered health tea or potato starch), linoleic acid and water in the ratio 4:1:1.5 by weight. Peroxide values were estimated and expressed in the same method as the legend in Fig.1. 
クッキーでは $\mathrm{Aw} 0.8$ 以上の高 $\mathrm{Aw}$ 領域では目立った $\mathrm{PV}$ 上昇はみられなかったが，Aw0.6で4 日目に約70の， Aw0.4以下の低 Aw 領域では 1 日目に1000を超える PV ピークが出現した。ヨモギ添加クッキーでは Aw0.8以 下で300〜 5000穏やかな PV 上昇がみられたが，シソ， 杉葉，ドクダミ添加クッキーに打いては，Aw0.6以上 の中間〜高 $\mathrm{Aw}$ 領域で安定した抗酸化能が認められた。 アミノ酸・ペプチド・タンパク質系に打いても同様に,

Aw 9 上昇に伴い抗酸化能が強まる傾向があり，それが 水分子による酸素分子の遮断効果であることが示唆され ている12)。健康茶粉末試料およびそれらをクッキーに添 加した場合の抗酸化能と Awの関係が，アミノ酸・ペ プチド・タンパク質系と類似していることから，健康茶 葉系に拈いても水分子による酸素分子遮断効果が酸化防 止に大きく寄与していることが示唆された。

本実験で検討した健康茶葉に含まれている抗酸化物質 については, 柿葉には, イソケルシトリン, アストラガ リンおよび（+）－カテキンが存在しラジカル捕捉活性 が強い10), ヨモギ, シソにはカフェータンニン, 前者に

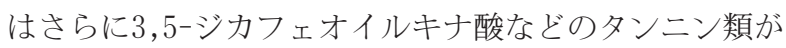
含まれている10), 18), 19)，ドクダミにはクェルセチン, クェルシトリン，イソクェルシトリン，レイノウトリン， ピペリンなどのフラボノイドが含まれている10),20),21), などの報告があり，未知成分の作用も否定できないが， 乾燥粉末系に抢いてはこれらが抗酸化活性の主体となっ ている可能性が高いものと考えられる。焼成中に生成す るメラノイジン ${ }^{22)}$,23), クッキーにおいては特にグルコー スとタンパク質との褐変生成物の生成過程で生じるレダ クトンの作用により油脂の酸化が防止されるとの報告も あるが23)，これらの作用は対照無添加クッキーに反映さ れ，事実上大きな効果は示されなかった（図 2 )。

本実験でいくつかの健康茶葉のクッキーへの添加が油 脂の酸化防止に有効であることが示唆されたことから， 焼成過程を経て作られる食品においても応用が可能であ ると考えられる。

\section{4. 要約}

市販の健康茶葉（柿葉，ヨモギ，シソ，杉葉，クマザ サ，八ス葉，ドクダミ）の乾燥粉末系に抢ける抗酸化能 について検討した。このうち, 抗酸化能が認められたも のについてさらにクッキーにこれらを添加したときの有 用性を検討した。

（1）対照ジャガイモデンプンは，保温開始 4 日以内に 全 Aw 領域において保温開始 4 日以内に大きな PVピー クが出現した。

（2）ハス葉およびクマザサでは低〜中間 Aw 領域で, 柿葉では低 $\mathrm{Aw}$ 領域で PV ピークが出現した。これに対 し, ヨモギ, シソ, 杉葉, ドクダミはすべて全 $\mathrm{Aw}$ 領 域で良好な抗酸化能が示された。

（3）対照ジャガイモデンプン添加クッキーは，保温開
始 6 日目までに大きな PVピークが出現した。

（4）柿葉添加クッキーの低 $\mathrm{Aw}$ 領域（Aw0.4以下） で対照と同レベルのPVピークが出現したが，ヨモギ, シソ，杉葉，ドクダミ添加クッキーでは全 Aw 領域で このような大きなピークはみられず，特に中間〜高 $\mathrm{Aw}$ 領域で強い抗酸化能が認められた。

\section{文献}

1）新津隆士：身の回りの化学, コロナ社, 東京, p.1-44 (2006)

2）中村好志, 小國伊太郎, 伊勢村護, 富田勲, 原征彦, 佐 野満昭, 横越英彦, 山本万里, 青島均, 芳野恭士 : 茶の化 学成分と機能, 弘学出版, 川崎, p.67-177 (2002)

3) 伊奈和夫 : 緑茶. 紅茶. 烏龍茶の化学と機能, 弘学出版, 川崎, p.123-136（1991）

4）村松敬一郎, 原征彦, 中村好志, 富田勲, 小國伊太郎, 大森正司, 並木和子 : 茶の科学, 朝倉書店, 東京, p.124191 (1991)

5）新津隆士：身の回りの化学, コロナ社, 東京, p.51-60 (2006)

6）下橋淳子 : 健康茶の DPPH ラジカル消去能と血栓溶解効 果, 駒沢女短紀要, 39, 35-39（2006）

7)鶴永陽子, 松崎一, 松本敏一, 冨川康之, 板村裕之: 製造 工程がヤマモモ葉茶のアスコルビン酸含量, ポリフェノー ル含量抢よびラジカル捕捉活性に与える影響, 日食保蔵誌, 32, 221-227 (2006)

8）鶴永陽子, 松崎一, 持田圭介, 松本敏一, 板村裕之: 蒸 熱加熱抒よび焙煎処理が保存中の柿葉茶の総アスコルビン 酸含量抢よびラジカル捕捉活性に与える影響, 日食科誌, 52, 391-397 (2005)

9）古庄律, 任良焃, 野口有希, 安原義, 天野良英, 片岡榮 子：自然発症ならびに実験的糖尿病ラットにおける血糖制 御, 脂質代謝および細胞性免疫能に及ぼす桑葉添加食摂取 の影響, 日食保蔵誌，30，271-276（2004）

10）棟久美佐子, 井上知明, 小松正幹：日本茶及び「健康茶」 浸出液の抗酸化性について（II）, 京都府保環研年報, 44, 20-25 (1999)

11）人見英里, 三浦裕美子, 三原香奈, 大西志麻, 原直子, 中野昌俊: 鉄含有クッキーに抢けるルイボスティーの抗酸 化能, 日食科誌，52，594-598（2005）

12）杉山薰, 姚薇, 冨岡和子: 乾燥粉末系におけるタンパク 質の抗酸化機構，日調科誌，33，348-357（2000）

13）杉山薰, 筒井延男, 冨岡和子: 粉末系における食品製造 副産物の抗酸化能とその利用, 醸協, 96，485-491（2001）

14）杉山薫, 姚薇, 冨岡和子: 粉末系における食品の抗酸化 能に及ぼす水分活性の影響, 日調科誌，33，339-347（2000）

15）杉山薰, 三村優, 尾原宏美, 冨岡和子 : 乾燥粉末系にお ける葛根水抽出物抢よび葛葉の抗酸化能, 日食保蔵誌, 30 , 243-246 (2004)

16）秋場稔：水産生物化学 - 食品学実験書, 恒星社厚生閣, 東京, p.341-351 (1974)

17) Mitsuda,H.,Yasumoto,K, and Iwami,K : Mechanism of antioxidation of amino acids in lipid oxidation, Memoirs College Agric., Kyoto University, 92, 1-16 (1967)

18）奥田拓男: 抗酸化物質, 学会出版センター, 東京, p.270 -272 (1994)

19）清水岑夫：生薬1010科学, 講談社, 東京, p.196-197 
健康茶を添加したクッキーの抗酸化能

(1999)

20）上海科学技術出版社 - 小学館編 : 中薬大辞典 (1), 小学 館, 東京, p.507-509 (1985)

21）清水岑夫：生薬1010科学, 講談社, 東京, p.145-146 (1999) 22）梶本五郎：抗酸化剂の理論と実際，三琇書房，横浜，p. 62-65 (1984)

23）八木一文, 秋谷年見：食品の酸化とその防止, 光琳, 東 京, p.95-126 (1967) 